\title{
The Role of Curcumin in Post-Ischemic Brain
}

\author{
Marta Rusek ${ }^{1,2} \bullet$ Stanisław J. Czuczwar ${ }^{1}$ \\ ${ }^{1}$ Department of Pathophysiology, Medical University of Lublin, Lublin, Poland; \\ ${ }^{2}$ Department of Dermatology, Venereology and Pediatric Dermatology, Laboratory for \\ Immunology of Skin Diseases, Medical University of Lublin, Lublin, Poland
}

Author for correspondence: Stanisław J. Czuczwar, Department of Pathophysiology, Medical University of Lublin, Lublin, Poland. Email: czuczwarsj@yahoo.com

Cite this chapter as: Rusek M, Czuczwar SJ. The Role of Curcumin in Post-Ischemic Brain. In: Pluta R, editor. Cerebral Ischemia. Brisbane (AU): Exon Publications; 2021. Online first Aug 17.

Doi: https://doi.org/10.36255/exonpublications.cerebralischemia.2021.curcumin

\begin{abstract}
Progressive accumulation of misfolded amyloid and tau protein in intracellular and extracellular spaces is the most crucial etiopathological feature of brain ischemia, synaptic damage, or neural communication impairment. Clinical data suggest that dietary intake of curcumin enhances neurogenesis and offers neuroprotection. Curcumin is a natural polyphenolic compound with diverse and attractive biological properties. It may prevent aging-associated changes in cellular proteins, such as $\beta$-amyloid peptide and tau protein, that lead to protein insolubility and aggregation after ischemic brain damage. Therefore, curcumin seems to be a promising supplementary agent against neurodegeneration development after brain ischemia. The aim of this chapter is to highlight our current understanding of the neuroprotective role of curcumin in cerebral ischemia-reperfusion injury. The limitations and adverse events of curcumin are also presented.
\end{abstract}

Keywords: amyloid; brain ischemia; curcumin; tau protein; neuroprotection

In: Cerebral Ischemia. Pluta R (Editor). Exon Publications, Brisbane, Australia. ISBN: 978-0-6450017-9-2; Doi: https://doi.org/10.36255/exonpublications. cerebralischemia.2021

Copyright: The Authors.

License: This open access article is licenced under Creative Commons Attribution-NonCommercial 4.0 International (CC BY-NC 4.0) https://creativecommons.org/licenses/by-nc/4.0/ 


\section{INTRODUCTION}

In both developing and developed countries, there is a tremendous increase in the prevalence of ischemia-related brain injury (1). Current epidemiological data indicate that 17 million patients suffer from ischemic stroke per year, 1.5 times higher in men than in women, of whom 6 million die each year $(2,3)$. Brain ischemia elicits complications, including motor dysfunction, depression, fatigue, progressive dementia, and Alzheimer's disease (AD)-type neuropathological changes. Moreover, outcomes after stroke frequently lead to a high risk of early rehospitalization and institutionalization, with adverse consequences in terms of socioeconomic costs (3).

Recent experimental and clinical data suggest that ischemia-related brain damage causes neurodegeneration of the brain through inflammation (4-9), accumulation of the $\beta$-amyloid $(A \beta)$ peptide pathway components $(2,9)$ outside the neurons due to cleavage of membrane-embedded proteins into neurotoxic single amyloidal units (10), and formation of neurofibrillary tangles (NFTs) $(11,12)$ inside the neurons due to the accumulation of paired helical filaments of hyperphosphorylated tau proteins (10). These changes damage neurons in different regions of the hippocampus, leading to brain atrophy and dysfunction $(1,13,14)$.

Currently, thrombolysis is the first choice of treatment during ischemic stroke in humans; however, it has a limited therapeutic window regarding the time after the incident (15). In addition, it does not affect the progressive changes that develop slowly during, and after, recirculation (15). Moreover, there is no available treatment to prevent brain ischemia and/or delay or stop neurodegeneration progression associated with ischemia. Also, the current drugs for $\mathrm{AD}$, such as acetylcholinesterase (AChE) inhibitors (galantamine and donepezil), rivastigmine (AChE and butyrylcholinesterase (BChE) inhibitor), and N-methyl-D-aspartate (NMDA) receptor antagonist memantine have not been able to significantly change the pathological process or provide improvements (16). Thus, the primary goal of drug discovery is to find or design neuroprotective molecules that are able to improve cognitive and motor functions after ischemia-related brain damage in $\mathrm{AD}$. Because of the lack of effective pharmacological options, alternative therapeutics such as nutraceuticals are evaluated. Several evidences suggest a significant correlation between lifestyle factors, diet, and the onset of dementia and AD development (17). The intake of a ketogenic diet, or diets rich in probiotics, antioxidants, and $\omega-3$ polyunsaturated fatty acids, or plant-based food may be beneficial to ameliorate the hallmarks of $\mathrm{AD}$ and other neurodegenerative diseases $(17,18)$. One of the promising dietary ingredient is curcumin, which displays a broad range of pharmacological activities, including antioxidant, anti-inflammatory (14), antibacterial, and antitumor actions (19).

Curcumin is a phytochemical extract from Curcuma longa rhizomes (19) of the Zingiberaceae (ginger) family. It is commonly used in Indian, Asian, and Middle Eastern cuisine. In Ayurvedic, traditional Persian, and Chinese medicines, it is used for its blood-purifying properties (20), treatment of skin and muscle inflammation, cough, sinusitis, allergy, bronchial dysfunctions, asthma, and hepatic disease (20). Chemically, it is known as diferuloylmethane $\left(\mathrm{C}_{21} \mathrm{H}_{20} \mathrm{O}_{6}\right)$, with a molecular mass of $368.37 \mathrm{~g} / \mathrm{mol}$. There are two aryl rings containing orthomethoxy phenolic OH-groups, symmetrically linked to a $\beta$-diketone moiety, which 
have an impact on the physicochemical properties, biological functions, and antioxidant activities of curcumin (21). In addition, it shows potential as a therapeutic option for cognitive impairment and $\mathrm{AD}$ treatment due to the ability to lower $\mathrm{A} \beta$ levels and inhibit $A \beta$ deposition and aggregation in mice (22), monkeys, bears (23), and humans (24). Moreover, it is a promising imaging agent for medical diagnostics (14).

\section{NEUROPATHOLOGY AFTER BRAIN ISCHEMIA}

Ischemic stroke in humans and animals is characterized by various neurobehavioral changes such as memory deficits, with a gradual decline in intellectual and cognitive functions (1). Eventually, it leads to dementia, which is a syndrome (or group of symptoms) that causes deterioration in behavior, ability to perform everyday tasks, memory, and learning capacity (25). Generally, it is not a normal part of aging but affects older groups of people (25). After ischemic brain damage, many changes occur in the brain, including the loss of neuronal cells in the CA2, CA3, and CA4 areas of the hippocampus $(1,9,13)$. In addition, acute and chronic neuronal changes are associated with a decrease in acetylcholine levels, suggesting insufficient neuronal excitable transmission $(26,27)$. Also, synaptophysin and 95-density postsynaptic protein levels changes were observed in the hippocampus after focal cerebral ischemia (27). Of note, transient brain ischemia leads to synaptic autophagy and neural loss $(28,29)$. In addition, this type of ischemia causes severe alterations in both the corpus callosum and subcortical white matter (30), and activation of glial cells in later stages (31). Brain ischemia results in increased permeability of the blood-brain barrier (BBB); thus, inflammatory cells may easily invade the brain tissue. Also, it facilitates the leakage of amyloid and tau protein from serum into the brain parenchyma $(30,32-35)$, which is an etiological factor for white matter damage. Inflammatory process is implied to be a significant component, which contributes to neurodegeneration progression. Inflammation was once considered a secondary process to ischemic neurodegeneration, but recent studies present that inflammatory mediators may stimulate amyloid protein precursor metabolism by upregulation of $\beta$-secretase (9).

Extensive research has revealed that brain ischemia is associated with numerous neuronal alterations, including $A \beta$ peptide production and accumulation, tau protein phosphorylation, NFT formation, mitochondrial damage, synaptic disappearance, microglia, and astrocyte activation $(1,2,7,9,11,36,37)$. These depositions of extracellular $A \beta$ plaques and intracellular accumulation of tau protein-containing NFTs are characteristic of neurodegenerative diseases, including $\mathrm{AD}$. Characteristic elements of this disease comprise extraneuronal senile plaques composed of $A \beta$ peptides 1-40 $\left(A \beta_{1-40}\right)$ and 1-42 $\left(A \beta_{1-42}\right)$ together with intraneuronal NFTs generated by phosphorylation of tau protein in the brain (13). The amyloid protein precursor and amyloid peptide are found to be upregulated in neurons and in extracellular space (8). Therefore, disruptions in A $\beta$ metabolism and/or $A \beta$ clearance contribute to $A D$ pathogenesis. Noteworthy, in experimental post-ischemic injury in the CAl and CA3 areas of the hippocampus and medial temporal cortex, the expression of genes related to AD is altered, including genes of the amyloid protein precursor, $\alpha$-secretase, $\beta$-secretase, presenilin 1 , 
presenilin 2, and tau protein (38). In addition, vascular damage and reactive gliosis are associated with deposits of amyloid in both ischemia-related brain injury and $\mathrm{AD}$ brain, which indicate the importance of the cerebrovasculature in further pathogenesis of $\mathrm{AD}(8)$.

\section{AMYLOID AFTER BRAIN ISCHEMIA}

The deposition of amyloid plaques, which are dense (39) or diffuse (40), is proposed to be a characteristic feature of the brain neurodegenerative diseases (41). These are mainly present in the hippocampus, ischemic cortex, entorhinal cortex, corpus callosum, and around the lateral ventricles (39) as well as thalamus (40). The A $\beta$ peptide is generated from amyloid protein precursor (APP) via sequential proteolytic processing by $\beta$-APP-cleaving enzyme-1 (BACE1) and $\gamma$-secretase to generate multiple $A \beta$ forms of varying amino acid lengths (14) that aggregate readily into oligomers and fibrils. The $A \beta_{1-42}$ form is postulated to be the most neurotoxic $A \beta$ species (42). They are mainly found in neurons, microglial cells (43), astrocytes (44), and oligodendrocytes $(1,45)$. The abnormal accumulation of $A \beta$ peptide may be involved in the repair of ischemic tissue followed by astrocyte cell loss $(1,36,44)$ and the development of glial scar $(36,44)$. Moreover, these changes are responsible for the development of leukoaraiosis after ischemic brain damage (46). Neurons affected by these deposits undergo synaptic degradation and neuronal cell death (47). Experimental data have shown that in cerebral ischemia, $A \beta$ peptide is generated as a result of neuronal injury and death (48), which contributes to the development of dementia with the AD phenotype through neurotoxic effects $(49,50)$.

\section{TAU PROTEIN AFTER BRAIN ISCHEMIA}

The major component of NFT is hyperphosphorylated tau protein, which may have a critical role in the progression of $\mathrm{AD}$ (42). It is observed in neurons, astrocytes, microglial cells, and oligodendrocytes after ischemia in both the hippocampus and cortex (51-54). Hyperphosphorylated tau protein is deposited as paired helical filaments in brain tissue (55), leading to neuronal apoptosis (56), followed by memory dysfunction (55). Interestingly, the concentration of tau protein is detectable in plasma after complete brain ischemia in humans within $96 \mathrm{~h}$; thus, it is a valuable biomarker of the progression of the neuronal changes during recirculation (35). Of note, the tau protein level can be useful as an indicator of neurological outcome after ischemia-reperfusion (35).

\section{RATIONALE FOR USING CURCUMIN AFTER BRAIN ISCHEMIA}

Curcumin is a neuroprotective molecule with potent antioxidant and antiinflammatory properties (57). These pleiotropic properties also reveal antiamyloid, anti-tau protein hyperphosphorylation, and anti-apoptotic action, as 
well as increasing neuronal lifespan and promoting neurogenesis (Figure 1). Experimental data show that curcumin may be one of the most interesting and promising natural pleiotropic molecules for the treatment of ischemic stroke and various brain diseases. Moreover, its physical and chemical properties, such as being hydrophobic and lipophilic, are beneficial (58). These properties affect the absorption, bioavailability, and half-life profiles of curcumin in the brain tissue (59). Moreover, this substance is safe, inexpensive, and easily accessible (1, 60).

Studies carried out in an animal model of $\operatorname{AD}(22,61)$, and humans (62-65) have shown that $A \beta$ metabolism is altered by curcumin. Also, curcumin may influence brain function and the development of dementia because of its antioxidant and anti-inflammatory properties, as well as its ability to influence A $\beta$ metabolism (14) and the accumulation of misfolded amyloid peptides $(2,11,13)$.

Anti-amyloid generation and aggregation

Anti-tau protein hyperphosphorylation
- Inhibits $A \beta$ aggregation and deposition

- Binds $A \beta$

- Blocks $A \beta$ self assembly - inhibits fibrillary $A \beta$ formation

- Inhibits upregulation of BACE1

- Inhibits AßPP metabolism

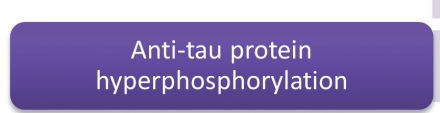

- Inhibits phosphorylation of tau protein

- Decreases NFT

- Inhibits inflammation

- Downregulates of NF-KB

Anti-inflammatory action

- Reduces activity of COX-2, 5-LOX, cytokines (TNF- $\alpha$, IL-1, IL-6)

- Activates of PPARy

- Mediates autophagy activity via PI3K/Akt/mTOR

- Inhibits GSH-3 $\beta$, activates Wnt signaling

\begin{tabular}{|c|c|c|c|c|}
\hline Antioxidant action & - Reduces oxidative stress \\
\hline Cognitive improvement & $\bullet$ Inhibits acetylcholinesterase activity \\
\hline
\end{tabular}

- Reduces neuronal apoptosis by increasing the anti-apoptotic $\mathrm{Bcl} 2$ protein at the mitochondrial level

Anti-apoptotic action

- Decreases cytosolic cytochrome c translocation

- Reduces apoptosis via caspase-3 mRNA downregulation

- Stimulates neurogenesis

- Reduces astrogliosis

- Inhibition of HIF-1 $\alpha$

- Promotes neuroplasticity, cell growth and neurogenesis

Figure 1. Potential mechanism of action of curcumin. Based on (14). 5-LOX, 5-lipoxygenase; AD, Alzheimer's disease; $A \beta, \beta$ amyloid; BACE1, $\beta$-APP-cleaving enzyme-1; COX-2, cyclooxygenase-2; HIF-1 $\alpha$, hypoxia-inducible factor 1-alpha; IL-1, interleukin-1; IL-6, interleukin-6; NFT, neurofibrillary tangles; NF-kB, nuclear factor kappa B; PPAR $\gamma$, peroxisome proliferator-activated receptor-gamma; TNF- $\alpha$, tumor necrosis factor- $\alpha$. 
Moreover, it inhibits phosphorylation of tau protein, thus decreasing NFT $(66,67)$. The basic strategy for developing treatment of post-ischemic neurodegeneration is to target all these pathways involved in its pathogenesis (68). Effective penetration of the BBB and neuronal membranes is necessary. Curcumin easily crosses the BBB $(68,69)$. Also, it binds and disaggregates oligomers and fibrils of amyloid peptides (70) and increases the clearance of amyloid (14).

\section{Anti-amyloid properties}

The A $\beta$ peptide is a product of amyloid protein precursor (APP). The generation of a $\beta$-amyloid peptide is catalyzed by enzymes such as $\beta$-secretase and $\gamma$-secretase. Of note, these enzymes are attractive targets for curcumin after cerebral ischemia. Curcumin inhibits $\beta$-secretase activity; thus, it has the potential to decrease $A \beta$ peptide levels $(57,70)$. Moreover, it inhibits the maturation of the APP and the amyloidogenic pathway, which contributes to a reduced $A \beta$ peptide concentration (71). Therefore, the modulation of APP by curcumin reduces amyloid levels due to the increased retention of the immature APP in the endoplasmic reticulum and interference with APP endocytosis (71). In addition, curcumin inhibits amyloid aggregation $(72,73)$, modulates the formation of nontoxic aggregates, reduces the toxicity of many amyloid conformers (e.g., monomeric, oligomeric, prefibrillar, and fibrillar amyloid), and decreases the permeability of the cell membrane induced by amyloid aggregates (74). Curcumin, as well as pyrazoles and isoxazoles (derived from curcumin) are able to destabilize $A \beta_{1-40}$ and $A \beta_{1-42}$ and inhibit the metabolism of $A \beta P P(75)$. Of note, the inhibition of $A \beta_{1-40}$ and $A \beta_{1-42}$ formation by curcumin is dose-dependent, where the most effective activity was observed with an $\mathrm{EC}_{50}$ of $0.09-0.63 \mu \mathrm{M}(70,76)$. Also, the high lipid content of brain tissue allows lipophilic curcumin to cross the BBB and inhibit the aggregation of amyloid proteins (58).

Brahmkhatri et al. found that polymeric nanoparticle-encapsulated curcumin conjugates with gold nanoparticles inhibited aggregation of the N-terminal area of amyloid and were able to dissolve aggregates (77). Also, Mithu et al. revealed that the $A \beta_{1-42}$ fibrils were disrupted by curcumin, which induced significant structural changes in the Asp-23-Lys-28 salt bridge region and near the C terminus (78). Moreover, Garcia-Alloza et al. demonstrated that systemic treatment with curcumin for 7 days cleared and reduced existing amyloid plaques in APPswe/PS1dE9 mice but also reversed structural changes in dystrophic dendrites, including abnormal curvature and dystrophy size (22). In addition, disruption of clearance is associated with the rise of $A \beta$ peptide in brain tissue. One way includes the transport of A $\beta$ peptide via LRPl across the BBB to the blood, followed by enzymes that degrade $A \beta$ peptide (79). Curcumin may bind to the $A \beta$ peptide and promote receptor-mediated efflux of $A \beta$ peptides (70). In addition, it suppresses the RAGE-mediated influx of $A \beta$ peptides across the BBB from blood. Moreover, curcumin may stimulate phagocytosis by activating microglial cells and increase the presence of phagocytic cells around $A \beta$ peptide deposits (68). The presence of two phenolic $(\mathrm{OH})$ groups and one active methylene $\left(\mathrm{CH}_{2}\right)$ group in curcumin makes it an excellent ligand for metal chelation, and may remove metal from amyloid (80). 


\section{Anti-tau properties}

Hyperphosphorylated tau protein as paired helical filaments is a component of NFT in brain ischemia (81). They change the cytoarchitecture of brain tissue, increase oxidative stress, cause mitochondrial dysfunction, and promote neurodegeneration (82). Therefore, the phosphorylation of tau protein may be a link between oxidative stress and cognitive decline. The tau protein hyperphosphorylation is modulated by several kinases, including glycogen synthase kinase-3 $\beta$ (GSK-3 $\beta$ ) and mitogen-activated protein kinase (MAPK) (82), cyclin-dependent kinase 5, S6 kinase, protein kinase A, calcium/calmodulin-dependent protein kinase II, SAD kinase, extracellular signal-regulated kinase 2, microtubule affinity-regulating kinase, and Src family kinases (Fyn and c-Abl). Therefore, a combined therapy involving these checkpoints could become a viable therapeutic option for ischemia-related brain damage and/or AD treatment (83). Curcumin has been found to inhibit tau protein aggregation, and disintegrate preformed tau protein oligomers and the formation of tau protein fibril (84). Moreover, it inhibits GSK-3 $\beta$ activity, diminishing tau protein dimer formation and hyperphosphorylated tau protein oligomerization in aged human tau protein transgenic mice (66).

\section{Anti-inflammatory action}

Another reason for using curcumin in therapy for neurological diseases is its ability to reduce neuroinflammation. It is a potential anti-inflammatory agent, which can downregulate many neuroinflammatory marker proteins, such as nuclear factor kappa B (NF-kB) (85). Curcumin is able to diminish the activity of cyclooxygenase-2 (COX-2) and 5-lipoxygenase (5-LOX), the enzymes involved in the arachidonic acid metabolism (86). Moreover, it reduces the levels of several cytokines, such as tumor necrosis factor- $\alpha$ (TNF- $\alpha$ ), interleukin-1 (IL-1), and interleukin-6 (IL-6) (87). It can activate the peroxisome proliferator-activated receptor-gamma (PPARY) (88). Besides reducing neuroinflammation, Wang et al. have shown that curcumin significantly decreased the expression of phosphatidylinositol 3-kinase (PI3K), phosphorylated Akt, and mTOR at protein levels (89). Curcumin mediates autophagy via PI3K/Akt/mTOR (90), which further suggests its neuroprotective effect (89). Of note, the important feature of curcumin is the ability to change the composition of bacterial populations and reduce intestinal inflammation (91). It has been proved that any changes in gut microbiota are associated with different pathologies, even with neurological diseases such as AD, schizophrenia, brain ischemia, and depressive disorders (92). Curcumin is a modulating factor of inflammation; thus, it impacts the gut-brain axis (91).

\section{Antioxidant action}

Curcumin acts as a powerful antioxidant in post-ischemic brain. High metabolic rate of the central nervous system, its increased demand for $\mathrm{O}_{2}$, and large quantities of membrane phospholipids and polyunsaturated fatty acids significantly 
contribute to an increase of reactive oxygen species, which may be present in chronic progressive neurological diseases (93). Curcumin is able to scavenge superoxide anions $\left(\mathrm{O}^{2-}\right)$ and hydroxyl radicals $\left(\mathrm{OH}^{-}\right)$, and increase antioxidant levels, such as glutathione (94). In addition, it protects cells from lipid peroxidation, DNA damage, and protein oxidation or protein carbonylation (95).

\section{Antiapoptotic action}

Curcumin diminished neuronal apoptosis by increasing the antiapoptotic Bcl2 protein at the mitochondrial level, and decreasing cytosolic cytochrome c translocation (96). In addition, it reduced apoptosis (97) via caspase-3 mRNA downregulation (90), decreased mitochondrial membrane potential (97). stimulated neurogenesis (98), and reduced astrogliosis (99). In a recent study, curcumin protected ischemic neurons from apoptosis through the neuroprotective effect associated with both autophagy and hypoxia-inducible factor 1-alpha (HIF-1 $\alpha$ ) inhibition (100). In addition, curcumin can inhibit the PP1 and Akt/p70S6K pathways to activate extracellular signal-regulated kinases (ERK1/2) and subsequent autophagy (101).

\section{Neuroprotective activity and neurogenesis}

Curcumin stimulates brain-derived neurotrophic factor (BDNF), nerve growth factor (NGF), glial cell-derived neurotrophic factor (GDNF), and plateletderived growth factor (PDGF) (102), which may enhance neurogenesis, synaptogenesis and improve cognition in rats (103). Besides, levels of synaptophysin and PSD95 can be restored in animal models of neurodegenerative diseases (104). Experimental studies show that curcumin reduced the volume of brain infarction and brain edema $(99,105)$. Curcumin improved motor and sensory activity; however, improvements in neurobehavioral and neurological deficits were minimal $(24,99)$. Another feature of curcumin is neuroprotection against local cerebral ischemia/reperfusion injury via the activation of Notch signaling pathway (98). It stimulated neurogenesis and decreased apoptotic index within three days of reperfusion (98). Moreover, curcumin played a role in neuroprotection through preventing lipid peroxidation and decreasing peroxynitrite, while increasing endogenous antioxidant enzymes in a cerebral ischemia model of rats (106). In addition, curcumin has been recognized to improve neurological function scores, maintain the integrity of the $\mathrm{BBB}$, and reduce the infarct volume of the cerebral cortex (1, 107, 108). Moreover, curcumin attenuated glutamate neurotoxicity in the hippocampus (107).

\section{Influence on microcirculation}

Another role of curcumin includes its impact on cerebral circulation, which can be improved by reduced adhesion of platelets in brain microvascular endothelial cells (BMECs) and inhibition of inflammation of blood vessels (109). However, curcumin may exhibit angiostatic abilities by controlling the expression of genes of metalloproteinase-9 (MMP-9) and vascular endothelial growth factor (VEGF), 
which are recognized as suppressors of extracellular matrix organization and initiating angiogenesis (110). Also, it enhanced the generation of granulation tissue, including rapid re-epithelialization and neo-vascularization in wound healing through modulation of the expression of TGF- $\beta 1$, its receptors, and nitric oxide synthase (111).

\section{Regulatory role on epigenetics}

Curcumin plays significant regulatory roles in modulating the methylation, acetylation, ubiquitination, and phosphorylation status of histone and other DNAbinding proteins (112), mainly by inhibiting histone acetyltransferases (HATs) activity and activating histone deacetylases (HDAC) in AD (112). Curcumin has been considered a selective inhibitor of the p300/CREB binding protein HAT activity (113). Therefore, curcumin can diminish the catalytic activity of HATs and inhibit nuclear histone acetylation that reduces the inflammation via the NF-kB pathway in some brain diseases (85).

\section{LIMITATIONS OF CURCUMIN TREATMENT AND SIDE EFFECTS}

Toxicological assessments have revealed that curcumin is a pharmacologically safe substance. The intake of $8 \mathrm{~g}$ daily in the short-term has been shown to exert no significant side effects (64). Similar effects were observed in a phase 1 study, with $8 \mathrm{~g}$ of curcumin daily for three months (80). To date, clinical studies of curcumin have revealed limited effects, most likely because of curcumin's relatively low solubility and bioavailability. Curcumin has poor water solubility, and it is unstable in most body fluids (68). In addition, the selection of cohorts with ischemiarelated brain damage or diagnosed $\mathrm{AD}$ has an impact on the effectiveness of this treatment because of pre-existing major neuropathologies. However, curcumin may have potential in targeting early brain ischemia or AD pathology (by treating healthy, pre-clinical, and mild cognitive impairment-stage cohorts). New curcumin formulations that increase bioavailability are renewing optimism concerning curcumin-based therapy (14). Several studies have shown that high doses of curcumin can cause adverse side effects, including headache, nausea, diarrhea, abdominal pain, yellow stool, skin rash, swelling of the skin, and dermatitis (64). Moreover, since curcumin may interact with some drugs, it is not recommended for people taking blood thinners, reserpine, or nonsteroid anti-inflammatory drugs (57).

\section{CONCLUSION}

Ischemia-reperfusion leads to neuronal damage and death, with misfolded protein deposits. In addition, it results in cognitive deficits and/or impairment of motor coordination with probable development of dementia of AD phenotype (28). Due to the pleiotropic influence of curcumin on the brain, including anti-amyloid, anti-tau protein, antioxidant, anti-inflammatory, and neuroprotective properties, 
curcumin is a promising candidate for the treatment of post-ischemic neurodegeneration with misfolded proteins (1). Therefore, this multi-functional therapeutic compound may have a potential clinical utility in the treatment of neurodegenerative disorders. Currently, the existing data of using curcumin as a therapeutic option in the ischemic-related brain diseases seems interesting. However, there are limited number of studies performed in humans. Further, it requires extensive, multi-center research efforts.

Acknowledgment: The authors acknowledge the financial support from the Medical University of Lublin, Lublin, Poland (DS 475/19-SJC).

Conflict of Interest: The authors declare no potential conflicts of interest with respect to research, authorship, and/or publication of this chapter.

Copyright and Permission Statement: To the best of our knowledge, the materials included in this chapter do not violate copyright laws. All original sources have been appropriately acknowledged and/or referenced. Where relevant, appropriate permissions have been obtained from the original copyright holder(s).

\section{REFERENCES}

1. Ułamek-Kozioł M, Czuczwar SJ, Januszewski S, Pluta R. Substantiation for the use of curcumin during the development of neurodegeneration after brain ischemia. Int J Mol Sci. 2020;21(2):517. https:// doi.org/10.3390/ijms21020517

2. Pluta R, Ułamek-Kozioł M, Januszewski S, Czuczwar S. Amyloid pathology in the brain after ischemia. Folia Neuropathol. 2019;57(3):220-226. https://doi.org/10.5114/fn.2019.88450

3. Béjot Y, Daubail B, Giroud M. Epidemiology of stroke and transient ischemic attacks: Current knowledge and perspectives. Rev Neurol. 2016;172(1):59-68. https://doi.org/10.1016/j.neurol.2015.07.013

4. Sawikr Y, Yarla NS, Peluso I, Kamal MA, Aliev G, Bishayee A. Neuroinflammation in Alzheimer's disease: the preventive and therapeutic potential of polyphenolic nutraceuticals. Adv Protein Chem Struct Biol. 2017;108:33-57. https://doi.org/10.1016/bs.apcsb.2017.02.001

5. Heneka MT, Carson MJ, El Khoury J, Landreth GE, Brosseron F, Feinstein DL, et al. Neuroinflammation in Alzheimer's disease. Lancet Neurol. 2015;14(4):388-405. https://doi.org/10.1016/S1474-4422(15) 70016-5

6. Phillips EC, Croft CL, Kurbatskaya K, O'Neill MJ, Hutton ML, Hanger DP, et al. Astrocytes and neuroinflammation in Alzheimer's disease. Biochem Soc Trans. 2014;42(5):1321-1325. https://doi. org/10.1042/BST20140155

7. Sekeljic V, Bataveljic D, Stamenkovic S, Ułamek M, Jabłoński M, Radenovic L, et al. Cellular markers of neuroinflammation and neurogenesis after ischemic brain injury in the long-term survival rat model. Brain Struct Funct. 2012;217(2):411-420. https://doi.org/10.1007/s00429-011-0336-7

8. Pluta R. Astroglial expression of the beta-amyloid in ischemia-reperfusion brain injury. Ann N Y Acad Sci. 2002;977:102-108. https://doi.org/10.1111/j.1749-6632.2002.tb04803.x

9. Pluta R, Ułamek M, Jabłoński M. Alzheimer’s mechanisms in ischemic brain degeneration. Anat Rec. 2009;292(12):1863-1881. https://doi.org/10.1002/ar.21018

10. Giacomeli R, Izoton JC, Dos Santos RB, Boeira SP, Jesse CR, Haas SE. Neuroprotective effects of curcumin lipid-core nanocapsules in a model Alzheimer's disease induced by $\beta$-amyloid 1-42 peptide in aged female mice. Brain Res. 2019;1721:146325. https://doi.org/10.1016/j.brainres.2019.146325 
11. Pluta R, Ułamek-Kozioł M, Januszewski S, Czuczwar SJ. Tau protein dysfunction after brain ischemia. J Alzheimers Dis. 2018;66(2):429-437. https://doi.org/10.3233/JAD-180772

12. Hatsuta H, Takao M, Nogami A, Uchino A, Sumikura H, Takata T, et al. Tau and TDP-43 accumulation of the basal nucleus of Meynert in individuals with cerebral lobar infarcts or hemorrhage. Acta Neuropathol Commun. 2019;7(1):49. https://doi.org/10.1186/s40478-019-0700-z

13. Pluta R, Ulamek-Koziol M, Januszewski Saa, J. Czuczwar S. From brain ischemia to Alzheimerlike neurodegeneration. Neuropsychiatry. 2018;08(05):1708-1714. https://doi.org/10.4172/ Neuropsychiatry. 1000510

14. Goozee KG, Shah TM, Sohrabi HR, Rainey-Smith SR, Brown B, Verdile G, et al. Examining the potential clinical value of curcumin in the prevention and diagnosis of Alzheimer's disease. Br J Nutr. 2016;115(3):449-465. https://doi.org/10.1017/S0007114515004687

15. Cassella CR, Jagoda A. Ischemic stroke: advances in diagnosis and management. Emerg Med Clin North Am. 2017;35(4):911-930. https://doi.org/10.1016/j.emc.2017.07.007

16. Briggs R, Kennelly SP, O'Neill D. Drug treatments in Alzheimer's disease. Clin Med. 2016;16(3): 247-253. https://doi.org/10.7861/clinmedicine.16-3-247

17. Rusek M, Pluta R, Ułamek-Kozioł M, Czuczwar SJ. Ketogenic diet in Alzheimer’s disease. Int J Mol Sci. 2019;20(16):3892. https://doi.org/10.3390/ijms20163892

18. Pistollato F, Iglesias RC, Ruiz R, Aparicio S, Crespo J, Lopez LD, et al. Nutritional patterns associated with the maintenance of neurocognitive functions and the risk of dementia and Alzheimer's disease: a focus on human studies. Pharmacol Res. 2018;131:32-43. https://doi.org/10.1016/j. phrs.2018.03.012

19. Park J-Y, Sohn H-Y, Koh YH, Jo C. Curcumin activates Nrf2 through PKC $\delta$-mediated p62 phosphorylation at Ser351. Sci Rep. 2021;11(1):8430. https://doi.org/10.1038/s41598-021-87225-8

20. Goel A, Kunnumakkara AB, Aggarwal BB. Curcumin as "Curecumin": from kitchen to clinic. Biochem Pharmacol. 2008;75(4):787-809. https://doi.org/10.1016/j.bcp.2007.08.016

21. Amalraj A, Pius A, Gopi S, Gopi S. Biological activities of curcuminoids, other biomolecules from turmeric and their derivatives - a review. J Tradit Complement Med. 2017;7(2):205-233. https://doi. org/10.1016/j.jtcme.2016.05.005

22. Garcia-Alloza M, Borrelli LA, Rozkalne A, Hyman BT, Bacskai BJ. Curcumin labels amyloid pathology in vivo, disrupts existing plaques, and partially restores distorted neurites in an Alzheimer mouse model. J Neurochem. 2007;102(4):1095-1104. https://doi.org/10.1111/j.1471-4159.2007.04613.x

23. Mutsuga M, Chambers JK, Uchida K, Tei M, Makibuchi T, Mizorogi T, et al. Binding of curcumin to senile plaques and cerebral amyloid angiopathy in the aged brain of various animals and to neurofibrillary tangles in Alzheimer's brain. J Vet Med Sci. 2012;74(1):51-57. https://doi.org/10.1292/ jvms.11-0307

24. Huang H-C, Chang P, Dai X-L, Jiang Z-F. Protective effects of curcumin on amyloid- $\beta$-induced neuronal oxidative damage. Neurochem Res. 2012;37(7):1584-1597. https://doi.org/10.1007/ s11064-012-0754-9

25. Shabbir U, Rubab M, Tyagi A, Oh D-H. Curcumin and Its Derivatives as Theranostic Agents in Alzheimer's Disease: The Implication of Nanotechnology. Int J Mol Sci. 2020;22(1):196. https://doi. org/10.3390/ijms22010196

26. Pluta R, Salínska E, Puka M, Stafiej A, Lazarewicz JW. Early changes in extracellular amino acids and calcium concentrations in rabbit hippocampus following complete 15-min cerebral ischemia. Resuscitation. 1988;16(3):193-210. https://doi.org/10.1016/0300-9572(88)90046-9

27. Scheff SW, Price DA, Schmitt FA, Scheff MA, Mufson EJ. Synaptic loss in the inferior temporal gyrus in mild cognitive impairment and Alzheimer's disease. J Alzheimers Dis. 2011;24(3):547-557. https:// doi.org/10.3233/JAD-2011-101782

28. Ułamek-Kozioł M, Czuczwar SJ, Januszewski S, Pluta R. Proteomic and genomic changes in tau protein, which are associated with alzheimer's disease after ischemia-reperfusion brain injury. Int J Mol Sci. 2020;21(3):892. https://doi.org/10.3390/ijms21030892

29. Hofmeijer J, van Putten MJAM. Ischemic cerebral damage: an appraisal of synaptic failure. Stroke. 2012;43(2):607-615. https://doi.org/10.1161/STROKEAHA.111.632943 
30. Pluta R, Ułamek M, Januszewski S. Micro-blood-brain barrier openings and cytotoxic fragments of amyloid precursor protein accumulation in white matter after ischemic brain injury in long-lived rats. Acta Neurochir Suppl. 2006;96:267-271. https://doi.org/10.1007/3-211-30714-1_57

31. Wakita H, Tomimoto H, Akiguchi I, Kimura J. Glial activation and white matter changes in the rat brain induced by chronic cerebral hypoperfusion: an immunohistochemical study. Acta Neuropathol. 1994;87(5):484-492. https://doi.org/10.1007/BF00294175

32. Pluta R. Blood-brain barrier dysfunction and amyloid precursor protein accumulation in microvascular compartment following ischemia-reperfusion brain injury with 1-year survival. Acta Neurochir Suppl. 2003;86:117-122. https://doi.org/10.1007/978-3-7091-0651-8_26

33. Zetterberg H, Mörtberg E, Song L, Chang L, Provuncher GK, Patel PP, et al. Hypoxia due to cardiac arrest induces a time-dependent increase in serum amyloid $\beta$ levels in humans. PLoS One. 2011;6(12):e28263. https://doi.org/10.1371/journal.pone.0028263

34. Lee PH, Bang OY, Hwang EM, Lee JS, Joo US, Mook-Jung I, et al. Circulating beta amyloid protein is elevated in patients with acute ischemic stroke. J Neural Transm. 2005;112(10):1371-1379. https:// doi.org/10.1007/s00702-004-0274-0

35. Randall J, Mörtberg E, Provuncher GK, Fournier DR, Duffy DC, Rubertsson S, et al. Tau proteins in serum predict neurological outcome after hypoxic brain injury from cardiac arrest: results of a pilot study. Resuscitation. 2013;84(3):351-356. https://doi.org/10.1016/j.resuscitation.2012.07.027

36. Pluta R. The role of apolipoprotein $\mathrm{E}$ in the deposition of beta-amyloid peptide during ischemiareperfusion brain injury. A model of early Alzheimer's disease. Ann N Y Acad Sci. 2000;903:324-334. https://doi.org/10.1111/j.1749-6632.2000.tb06383.x

37. Qi J-P, Wu H, Yang Y, Wang D-D, Chen Y-X, Gu Y-H, et al. Cerebral ischemia and Alzheimer's disease: the expression of amyloid-beta and apolipoprotein $\mathrm{E}$ in human hippocampus. J Alzheimers Dis. 2007;12(4):335-341. https://doi.org/10.3233/JAD-2007-12406

38. Pluta R, Januszewski S, Czuczwar SJ. Brain Ischemia as a prelude to Alzheimer's disease. Front Aging Neurosci. 2021;13:636653. https://doi.org/10.3389/fnagi.2021.636653

39. Yam PS, Takasago T, Dewar D, Graham DI, McCulloch J. Amyloid precursor protein accumulates in white matter at the margin of a focal ischaemic lesion. Brain Res. 1997;760(1-2):150-157. https://doi. org/10.1016/S0006-8993(97)00290-4

40. van Groen T, Puurunen K, Mäki H-M, Sivenius J, Jolkkonen J. Transformation of diffuse beta-amyloid precursor protein and beta-amyloid deposits to plaques in the thalamus after transient occlusion of the middle cerebral artery in rats. Stroke. 2005;36(7):1551-1556. https://doi.org/10.1161/01. STR.0000169933.88903.cf

41. Ittner LM, Götz J. Amyloid- $\beta$ and tau--a toxic pas de deux in Alzheimer's disease. Nat Rev Neurosci. 2011;12(2):65-72. https://doi.org/10.1038/nrn2967

42. Villemagne VL, Burnham S, Bourgeat P, Brown B, Ellis KA, Salvado O, et al. Amyloid $\beta$ deposition, neurodegeneration, and cognitive decline in sporadic Alzheimer's disease: a prospective cohort study. Lancet Neurol. 2013;12(4):357-67. https://doi.org/10.1016/S1474-4422(13)70044-9

43. Banati RB, Gehrmann J, Wiessner C, Hossmann KA, Kreutzberg GW. Glial expression of the betaamyloid precursor protein (APP) in global ischemia. J Cereb Blood Flow Metab. 1995;15(4):647-54. https://doi.org/10.1038/jcbfm.1995.80

44. Takuma K, Baba A, Matsuda T. Astrocyte apoptosis: implications for neuroprotection. Prog Neurobiol. 2004;72(2):111-127. https://doi.org/10.1016/j.pneurobio.2004.02.001

45. Pluta R. Experimental model of neuropathological changes characteristic for Alzheimer's disease. Folia Neuropathol. 1997;35(2):94-98.

46. Pluta R, Januszewski S, Ułamek M. Ischemic blood-brain barrier and amyloid in white matter as etiological factors in leukoaraiosis. Acta Neurochir Suppl. 2008;102:353-356. https://doi. org/10.1007/978-3-211-85578-2_67

47. Oster-Granite ML, McPhie DL, Greenan J, Neve RL. Age-dependent neuronal and synaptic degeneration in mice transgenic for the $\mathrm{C}$ terminus of the amyloid precursor protein. J Neurosci. 1996;16(21):6732-6741. https://doi.org/10.1523/JNEUROSCI.16-21-06732.1996

48. Ishimaru H, Ishikawa K, Haga S, Shoji M, Ohe Y, Haga C, et al. Accumulation of apolipoprotein $\mathrm{E}$ and beta-amyloid-like protein in a trace of the hippocampal CAl pyramidal cell layer 
after ischaemic delayed neuronal death. Neuroreport. 1996;7(18):3063-3067. https://doi. org/10.1097/00001756-199611250-00054

49. Pluta R, Ułamek-Kozioł M, Januszewski S, Sciślewska M, Bogucka-Kocka A, Kocki J. Alzheimer’s factors in postischemic dementia. Rom J Morphol Embryol. 2012;53(3):461-466.

50. Giulian D, Haverkamp LJ, Li J, Karshin WL, Yu J, Tom D, et al. Senile plaques stimulate microglia to release a neurotoxin found in Alzheimer brain. Neurochem Int. 1995;27(1):119-137. https://doi. org/10.1016/0197-0186(95)00067-I

51. Sinigaglia-Coimbra R, Cavalheiro EA, Coimbra CG. Postischemic hyperthermia induces Alzheimerlike pathology in the rat brain. Acta Neuropathol. 2002;103(5):444-452. https://doi.org/10.1007/ s00401-001-0487-3

52. Dewar D, Graham DI, Teasdale GM, McCulloch J. Cerebral ischemia induces alterations in tau and ubiquitin proteins. Dementia. 1994;5(3-4):168-173. https://doi.org/10.1159/000106716

53. Dewar D, Dawson D. Tau protein is altered by focal cerebral ischaemia in the rat: an immunohistochemical and immunoblotting study. Brain Res. 1995;684(1):70-78. https://doi. org/10.1016/0006-8993(95)00417-O

54. Uchihara T, Nakamura A, Arai T, Ikeda K, Tsuchiya K. Microglial tau undergoes phosphorylationindependent modification after ischemia. Glia. 2004;45(2):180-187. https://doi.org/10.1002/ glia. 10318

55. Khan S, Yuldasheva NY, Batten TFC, Pickles AR, Kellett KAB, Saha S. Tau pathology and neurochemical changes associated with memory dysfunction in an optimised murine model of global cerebral ischaemia - A potential model for vascular dementia? Neurochem Int. 2018;118:134-144. https://doi. org/10.1016/j.neuint.2018.04.004

56. Wen Y, Yang S, Liu R, Simpkins JW. Transient cerebral ischemia induces site-specific hyperphosphorylation of tau protein. Brain Res. 2004;1022(1-2):30-38. https://doi.org/10.1016/j. brainres.2004.05.106

57. Cole GM, Teter B, Frautschy SA. Neuroprotective effects of curcumin. Adv Exp Med Biol. 2007;595:197-212. https://doi.org/10.1007/978-0-387-46401-5_8

58. Priyadarsini KI. The chemistry of curcumin: from extraction to therapeutic agent. Molecules. 2014;19(12):20091-20112. https://doi.org/10.3390/molecules191220091

59. Anand P, Kunnumakkara AB, Newman RA, Aggarwal BB. Bioavailability of curcumin: problems and promises. Mol Pharm. 2007;4(6):807-818. https://doi.org/10.1021/mp700113r

60. Sharifi-Rad J, Rayess Y El, Rizk AA, Sadaka C, Zgheib R, Zam W, et al. Turmeric and its major compound curcumin on health: bioactive effects and safety profiles for food, pharmaceutical, biotechnological and medicinal applications. Front Pharmacol. 2020;11:1021. https://doi.org/10.3389/ fphar.2020.01021

61. Yang F, Lim GP, Begum AN, Ubeda OJ, Simmons MR, Ambegaokar SS, et al. Curcumin inhibits formation of amyloid beta oligomers and fibrils, binds plaques, and reduces amyloid in vivo. J Biol Chem. 2005;280(7):5892-5901. https://doi.org/10.1074/jbc.M404751200

62. Tang M, Taghibiglou C. The mechanisms of action of curcumin in Alzheimer's disease. J Alzheimers Dis. 2017;58(4):1003-1016. https://doi.org/10.3233/JAD-170188

63. Sundaram JR, Poore CP, Sulaimee NH Bin, Pareek T, Cheong WF, Wenk MR, et al. Curcumin ameliorates neuroinflammation, neurodegeneration, and memory deficits in p25 transgenic mouse model that bears hallmarks of Alzheimer's disease. J Alzheimers Dis. 2017;60(4):1429-1442. https://doi. org/10.3233/JAD-170093

64. Gupta SC, Patchva S, Aggarwal BB. Therapeutic roles of curcumin: lessons learned from clinical trials. AAPS J. 2013;15(1):195-218. https://doi.org/10.1208/s12248-012-9432-8

65. Ringman JM, Frautschy SA, Teng E, Begum AN, Bardens J, Beigi M, et al. Oral curcumin for Alzheimer's disease: tolerability and efficacy in a 24-week randomized, double blind, placebo-controlled study. Alzheimers Res Ther. 2012;4(5):43. https://doi.org/10.1186/alzrt146

66. Ma Q-L, Zuo X, Yang F, Ubeda OJ, Gant DJ, Alaverdyan M, et al. Curcumin suppresses soluble tau dimers and corrects molecular chaperone, synaptic, and behavioral deficits in aged human tau transgenic mice. J Biol Chem. 2013;288(6):4056-4065. https://doi.org/10.1074/jbc.M112.393751 
67. Mohorko N, Repovs G, Popović M, Kovacs GG, Bresjanac M. Curcumin labeling of neuronal fibrillar tau inclusions in human brain samples. J Neuropathol Exp Neurol. 2010;69(4):405-14. https://doi. org/10.1097/NEN.0b013e3181d709eb

68. Maiti P, Dunbar GL. Use of curcumin, a natural polyphenol for targeting molecular pathways in treating age-related neurodegenerative diseases. Int J Mol Sci. 2018;19(6):1637. https://doi.org/10.3390/ ijms19061637

69. Maiti P, Hall TC, Paladugu L, Kolli N, Learman C, Rossignol J, et al. A comparative study of dietary curcumin, nanocurcumin, and other classical amyloid-binding dyes for labeling and imaging of amyloid plaques in brain tissue of $5 x$-familial Alzheimer's disease mice. Histochem Cell Biol. 2016;146(5):609-625. https://doi.org/10.1007/s00418-016-1464-1

70. Yang F, Lim GP, Begum AN, Ubeda OJ, Simmons MR, Ambegaokar SS, et al. Curcumin inhibits formation of amyloid $\beta$ oligomers and fibrils, binds plaques, and reduces amyloid in vivo. J Biol Chem. 2005;280(7):5892-5901. https://doi.org/10.1074/jbc.M404751200

71. Zhang C, Browne A, Child D, Tanzi RE. Curcumin decreases amyloid-beta peptide levels by attenuating the maturation of amyloid-beta precursor protein. J Biol Chem. 2010;285(37):28472-28480. https://doi.org/10.1074/jbc.M110.133520

72. Kim H, Park B-S, Lee K-G, Choi CY, Jang SS, Kim Y-H, et al. Effects of naturally occurring compounds on fibril formation and oxidative stress of beta-amyloid. J Agric Food Chem. 2005;53(22): 8537-8541. https://doi.org/10.1021/jf051985c

73. Hu S, Maiti P, Ma Q, Zuo X, Jones MR, Cole GM, et al. Clinical development of curcumin in neurodegenerative disease. Expert Rev Neurother. 2015;15(6):629-637. https://doi.org/10.1586/14737175.2 015.1044981

74. Thapa A, Jett SD, Chi EY. Curcumin attenuates amyloid- $\beta$ aggregate toxicity and modulates amyloid- $\beta$ aggregation pathway. ACS Chem Neurosci. 2016;7(1):56-68. https://doi.org/10.1021/ acschemneuro.5b00214

75. Park S-Y, Kim DSHL. Discovery of natural products from Curcuma longa that protect cells from beta-amyloid insult: a drug discovery effort against Alzheimer's disease. J Nat Prod. 2002;65(9):12271231. https://doi.org/10.1021/np010039x

76. Ono K, Hasegawa K, Naiki H, Yamada M. Curcumin has potent anti-amyloidogenic effects for Alzheimer's beta-amyloid fibrils in vitro. J Neurosci Res. 2004;75(6):742-750. https://doi. org/10.1002/jnr.20025

77. Brahmkhatri VP, Sharma N, Sunanda P, D'Souza A, Raghothama S, Atreya HS. Curcumin nanoconjugate inhibits aggregation of N-terminal region (A $\beta-16)$ of an amyloid beta peptide. New J Chem. 2018;42(24):19881-19892. https://doi.org/10.1039/C8NJ03541E

78. Mithu VS, Sarkar B, Bhowmik D, Das AK, Chandrakesan M, Maiti S, Madhu PK. Curcumin alters the salt bridge-containing turn region in amyloid beta(1-42) aggregates. J Biol Chem. 2014;289(16): 11122-11131. https://doi.org/10.1074/jbc.M113.519447.

79. Thal DR. Clearance of amyloid $\beta$-protein and its role in the spreading of Alzheimer's disease pathology. Front Aging Neurosci. 2015;7:25. https://doi.org/10.3389/fnagi.2015.00025

80. Mishra S, Palanivelu K. The effect of curcumin (turmeric) on Alzheimer's disease: An overview. Ann Indian Acad Neurol. 2008;11(1):13-19. https://doi.org/10.4103/0972-2327.40220

81. Kato T, Hirano A, Katagiri T, Sasaki H, Yamada S. Neurofibrillary tangle formation in the nucleus basalis of Meynert ipsilateral to a massive cerebral infarct. Ann Neurol. 1988;23(6):620-623. https:// doi.org/10.1002/ana.410230617

82. Mondragón-Rodríguez S, Perry G, Zhu X, Moreira PI, Acevedo-Aquino MC, Williams S. Phosphorylation of tau protein as the link between oxidative stress, mitochondrial dysfunction, and connectivity failure: implications for Alzheimer's disease. Oxid Med Cell Longev. 2013;2013:940603. https://doi.org/10.1155/2013/940603

83. Stoothoff WH, Johnson GVW. Tau phosphorylation: physiological and pathological consequences. Biochim Biophys Acta. 2005;1739(2-3):280-297. https://doi.org/10.1016/j.bbadis.2004.06.017

84. Rane JS, Bhaumik P, Panda D. Curcumin inhibits tau aggregation and disintegrates preformed tau filaments in vitro. J Alzheimers Dis. 2017;60(3):999-1014. https://doi.org/10.3233/JAD-170351 
85. Biswas SK, McClure D, Jimenez LA, Megson IL, Rahman I. Curcumin induces glutathione biosynthesis and inhibits NF-kappaB activation and interleukin-8 release in alveolar epithelial cells: mechanism of free radical scavenging activity. Antioxid Redox Signal. 2005;7(1-2):32-41. https://doi.org/10.1089/ ars.2005.7.32

86. Hong J, Bose M, Ju J, Ryu J-H, Chen X, Sang S, et al. Modulation of arachidonic acid metabolism by curcumin and related beta-diketone derivatives: effects on cytosolic phospholipase A(2), cyclooxygenases and 5-lipoxygenase. Carcinogenesis. 2004;25(9):1671-1679. https://doi.org/10.1093/carcin/ bgh 165

87. Gulcubuk A, Altunatmaz K, Sonmez K, Haktanir-Yatkin D, Uzun H, Gurel A, et al. Effects of curcumin on tumour necrosis factor-alpha and interleukin-6 in the late phase of experimental acute pancreatitis. J Vet Med A Physiol Pathol Clin Med. 2006;53(1):49-54. https://doi. org/10.1111/j.1439-0442.2006.00786.x

88. Mazidi M, Karimi E, Meydani M, Ghayour-Mobarhan M, Ferns GA. Potential effects of curcumin on peroxisome proliferator-activated receptor- $\gamma$ in vitro and in vivo. World J Methodol. 2016;6(1): 112-117. https://doi.org/10.5662/wjm.v6.il.112

89. Wang C, Zhang X, Teng Z, Zhang T, Li Y. Downregulation of PI3K/Akt/mTOR signaling pathway in curcumin-induced autophagy in APP/PS1 double transgenic mice. Eur J Pharmacol. 2014;740: 312-320. https://doi.org/10.1016/j.ejphar.2014.06.051

90. Huang L, Chen C, Zhang X, Li X, Chen Z, Yang C, et al. Neuroprotective Effect of Curcumin Against Cerebral Ischemia-Reperfusion Via Mediating Autophagy and Inflammation. J Mol Neurosci. 2018;64(1):129-139. https://doi.org/10.1007/s12031-017-1006-x

91. Di Meo F, Margarucci S, Galderisi U, Crispi S, Peluso G. Curcumin, gut microbiota, and neuroprotection. Nutrients. 2019;11(10). https://doi.org/10.3390/nul1102426

92. Zhuang Z, Yang R, Wang W, Qi L, Huang T. Associations between gut microbiota and Alzheimer's disease, major depressive disorder, and schizophrenia. J Neuroinflammation. 2020;17(1):288. https:// doi.org/10.1186/s12974-020-01961-8

93. Gregersen N, Bross P. Protein misfolding and cellular stress: an overview. Methods Mol Biol. 2010;648:3-23. https://doi.org/10.1007/978-1-60761-756-3_1

94. Menon VP, Sudheer AR. Antioxidant and anti-inflammatory properties of curcumin. Adv Exp Med Biol. 2007;595:105-125. https://doi.org/10.1007/978-0-387-46401-5_3

95. Jat D, Parihar P, Kothari SC, Parihar MS. Curcumin reduces oxidative damage by increasing reduced glutathione and preventing membrane permeability transition in isolated brain mitochondria. Cell Mol Biol. 2013;59 Suppl:OL1899-905.

96. Zhao J, Yu S, Zheng W, Feng G, Luo G, Wang L, et al. Curcumin improves outcomes and attenuates focal cerebral ischemic injury via antiapoptotic mechanisms in rats. Neurochem Res. 2010;35(3): 374-379. https://doi.org/10.1007/s11064-009-0065-y

97. Mukherjee A, Sarkar S, Jana S, Swarnakar S, Das N. Neuro-protective role of nanocapsulated curcumin against cerebral ischemia-reperfusion induced oxidative injury. Brain Res. 2019;1704: 164-173. https://doi.org/10.1016/j.brainres.2018.10.016

98. Liu S, Cao Y, Qu M, Zhang Z, Feng L, Ye Z, et al. Curcumin protects against stroke and increases levels of Notch intracellular domain. Neurol Res. 2016;38(6):553-559. https://doi.org/10.1080/01616412. 2016.1187804

99. Kalani A, Chaturvedi P, Kamat PK, Maldonado C, Bauer P, Joshua IG, et al. Curcumin-loaded embryonic stem cell exosomes restored neurovascular unit following ischemia-reperfusion injury. Int J Biochem Cell Biol. 2016;79:360-369. https://doi.org/10.1016/j.biocel.2016.09.002

100. Hou Y, Wang J, Feng J. The neuroprotective effects of curcumin are associated with the regulation of the reciprocal function between autophagy and HIF-l $\alpha$ in cerebral ischemia-reperfusion injury. Drug Des Devel Ther. 2019;13:1135-1144. https://doi.org/10.2147/DDDT.S194182

101. Aoki H, Takada Y, Kondo S, Sawaya R, Aggarwal BB, Kondo Y. Evidence that curcumin suppresses the growth of malignant gliomas in vitro and in vivo through induction of autophagy: role of Akt and extracellular signal-regulated kinase signaling pathways. Mol Pharmacol. 2007;72(1):29-39. https:// doi.org/10.1124/mol.106.033167 
102. Gupta SC, Prasad S, Kim JH, Patchva S, Webb LJ, Priyadarsini IK, et al. Multitargeting by curcumin as revealed by molecular interaction studies. Nat Prod Rep. 2011;28(12):1937-1955. https://doi. org/10.1039/clnp0005la

103. Dong S, Zeng Q, Mitchell ES, Xiu J, Duan Y, Li C, et al. Curcumin enhances neurogenesis and cognition in aged rats: implications for transcriptional interactions related to growth and synaptic plasticity. PLoS One. 2012;7(2):e31211. https://doi.org/10.1371/journal.pone.0031211

104. Ahmed T, Enam SA, Gilani AH. Curcuminoids enhance memory in an amyloid-infused rat model of Alzheimer's disease. Neuroscience. 2010;169(3):1296-1306. https://doi.org/10.1016/j. neuroscience.2010.05.078

105. Jiang J, Wang W, Sun YJ, Hu M, Li F, Zhu DY. Neuroprotective effect of curcumin on focal cerebral ischemic rats by preventing blood-brain barrier damage. Eur J Pharmacol. 2007;561(1-3):54-62. https://doi.org/10.1016/j.ejphar.2006.12.028

106. Thiyagarajan M, Sharma SS. Neuroprotective effect of curcumin in middle cerebral artery occlusion induced focal cerebral ischemia in rats. Life Sci. 2004;74(8):969-985. https://doi.org/10.1016/j. lfs.2003.06.042

107. Li Y, Li J, Li S, Li Y, Wang X, Liu B, et al. Curcumin attenuates glutamate neurotoxicity in the hippocampus by suppression of ER stress-associated TXNIP/NLRP3 inflammasome activation in a manner dependent on AMPK. Toxicol Appl Pharmacol. 2015;286(1):53-63. https://doi.org/10.1016/j. taap.2015.03.010

108. Li W, Suwanwela NC, Patumraj S. Curcumin by down-regulating NF-kB and elevating Nrf2, reduces brain edema and neurological dysfunction after cerebral I/R. Microvasc Res. 2016;106:117-127. https://doi.org/10.1016/j.mvr.2015.12.008

109. Zhang L, Gu Z, Qin Z, Liang Z. Effect of curcumin on the adhesion of platelets to brain microvascular endothelial cells in vitro. Acta Pharmacol Sin. 2008;29(7):800-807. https://doi.org/10.1111/ j.1745-7254.2008.00813.x

110. Kim JH, Shim JS, Lee S-K, Kim K-W, Rha SY, Chung HC, et al. Microarray-based analysis of antiangiogenic activity of demethoxycurcumin on human umbilical vein endothelial cells: crucial involvement of the down-regulation of matrix metalloproteinase. Jpn J Cancer Res. 2002;93(12):1378-1385. https://doi.org/10.1111/j.1349-7006.2002.tb01247.x

111. Mani H, Sidhu GS, Kumari R, Gaddipati JP, Seth P, Maheshwari RK. Curcumin differentially regulates TGF-betal, its receptors and nitric oxide synthase during impaired wound healing. Biofactors. 2002;16(1-2):29-43. https://doi.org/10.1002/biof.5520160104

112. Reuter S, Gupta SC, Park B, Goel A, Aggarwal BB. Epigenetic changes induced by curcumin and other natural compounds. Genes Nutr. 2011;6(2):93-108. https://doi.org/10.1007/s12263-011-0222-1

113. Hassan F-U, Rehman MS-U, Khan MS, Ali MA, Javed A, Nawaz A, et al. Curcumin as an alternative epigenetic modulator: mechanism of action and potential effects. Front Genet. 2019;10:514. https:// doi.org/10.3389/fgene.2019.00514 